\title{
Antibiotic use in animal husbandry: A mixed-methods study among general community in Boyolali, Indonesia
}

\author{
Hidayah Karuniawati ${ }^{1,2}$, Mohamed Azmi Ahmad Hassali²(D), Wan Ismahanisa Ismail ${ }^{3}$, Taufik Taufik ${ }^{4}$ (D) and \\ Sri Suryawati ${ }^{i}$
}

\begin{abstract}
1. Department of Pharmacology and Clinical Pharmacy, Faculty of Pharmacy, Universitas Muhammadiyah Surakarta, Surakarta, Indonesia; 2. Discipline of Social and Administrative Pharmacy, School of Pharmaceutical Sciences, Universiti Sains Malaysia, Gelugor, Malaysia; 3. Department of Medical Laboratory Technology, Faculty of Health Sciences, Universiti Teknologi MARA, Cawangan, Pulau Pinang, Malaysia; 4. Department of Psychology, Faculty of Psychology, Universitas Muhammadiyah Surakarta, Surakarta, Indonesia; 5. Department of Pharmacology and Therapeutics, Faculty of Medicines, Public Health, and Nursing, Universitas Gadjah Mada, Yogyakarta, Indonesia. Corresponding author: Hidayah Karuniawati, e-mail: hk170@ums.ac.id

Co-authors: MAAH: azmihassali@gmail.com, WII: wanismahanisa@gmail.com, TT: taufik@ums.ac.id, SS: suryawati.farklin@gmail.com

Received: 29-12-2020, Accepted: 06-04-2021, Published online: 19-05-2021
\end{abstract}

doi: www.doi.org/10.14202/IJOH.2021.122-127 How to cite this article: Karuniawati H, Hassali MAA, Ismail WI, Taufik T, Suryawati S (2021) Antibiotic use in animal husbandry: A mixed-methods study among general community in Boyolali, Indonesia, Int. J. One Health, 7(1): 122-127.

\begin{abstract}
Background and Aim: Antibiotic resistance is one of the most serious problems worldwide. One predictive factor of increasing antibiotics resistance is the use of antibiotics in animals. This study aimed to explore the use of antibiotics for animal husbandry in a general community in Indonesia.

Materials and Methods: A concurrent mixed-methods study was conducted. Data were collected from 407 respondents using a questionnaire, followed by an in-depth interview in 12 respondents. Data were analyzed both quantitatively and qualitatively.

Results: Forty-two (10.32\%) of 407 respondents used antibiotics for animal husbandry. Of these 42 , $>60 \%$ occasionally bought antibiotics from the pharmacy without prescription and 50\% used their leftover antibiotics. Respondents also bought antibiotics from food stalls and animal feed shops. Tetracycline and amoxicillin were the most common antibiotics used for animal husbandry. The majority of respondents used antibiotics for therapeutic purposes and received information about using antibiotics for animal husbandry from friends and neighbors. Most of the respondents used antibiotics for animal husbandry incorrectly and had never heard of antibiotics resistance.
\end{abstract}

Conclusion: Inappropriate antibiotic use in animal husbandry was common in the community. Education on the prudent use of antibiotics for animal husbandry is needed.

Keywords: animal husbandry, antibiotic resistance, antibiotics, mixed-method.

\section{Introduction}

Antibiotic resistance is a serious problem nationally and globally. Antibiotic resistance has wide-ranging effects on health, the environment, and the economy. Resistance will cause antibiotics to be ineffective in inhibiting or killing bacteria and will result in treatment failures, longer hospital stays, increased risks of complications, and resultant increased morbidity and mortality. Misuse and overuse of antibiotics in humans are significantly related to increased resistance, and the inappropriate use of antibiotics for animal husbandry will increase the risk of resistance [1,2].

It is believed that animals raised on-farm consume nearly $50 \%$ of all antibiotics produced worldwide. Indeed, $80 \%$ of the antibiotics sold in the

Copyright: Karuniawati, et al. This article is an open access article distributed under the terms of the Creative Commons Attribution 4.0 International License (http://creativecommons.org/ licenses/ by/4.0/), which permits unrestricted use, distribution, and reproduction in any medium, provided you give appropriate credit to the original author(s) and the source, provide a link to the Creative Commons license, and indicate if changes were made. The Creative Commons Public Domain Dedication waiver (http:// creativecommons.org/ publicdomain/zero/1.0/) applies to the data made available in this article, unless otherwise stated.
Netherlands and the United States were used for livestock farming (broilers, turkey, pigs, veal calves, and other cattle) $[3,4]$. The consumption of antibiotics on farms to treat or minimize disease outbreaks or to promote animal growth is very high. The problem will increase if antibiotics are used inappropriately in animals, for example, as prophylactics and to increase growth. The use of antibiotics for livestock growth promotion is prohibited in Europe but is still widely practiced outside Europe [2].

The use of antibiotics in animal husbandry could increase the risk of antibiotic resistance. The inappropriate use of antibiotics causes resistant bacteria to multiply. Because animals typically live in groups, the spread of resistant bacteria to other animals is increased. A study in Indonesia revealed that the antibiotic resistance of Escherichia coli isolated from chicken carcasses in Jakarta to amoxicillin and tetracycline was as high as 73\% and 93\%, respectively; antibiotic-resistant Staphylococcus hadar was also reported [5].

The presence of resistant bacteria in animal husbandry has an impact on human health, as this will 
increase exposure to resistant bacteria in humans [2]. Antibiotic resistance in foods derived from animals has almost tripled since 2000 [6]. Some foodborne bacteria that have become resistant, such as Enterococci, Campylobacter, Salmonella, and E. coli, can transfer resistant genes to humans through food chains or direct contact $[7,8]$. A study in two major cities in Indonesia (Surabaya and Semarang) revealed that Staphylococcus aureus isolates from individuals in the community were resistant to tetracycline $(24.9 \%)$ [9]. Another study revealed that methicillin-resistant $S$. aureus was found among 263 isolates from healthy people in the community $[10,11]$.

Therefore, identification of the source of bacterial resistance to antibiotics can reduce the spread of resistance. In Indonesia, there has been no research on the use of antibiotics in animals by the general public. This study aimed to explore the use of antibiotics for animal husbandry in a general community in Indonesia.

\section{Materials and Methods}

\section{Ethical approval and Informed consent}

Ethical approval was obtained from the Medical and Health Research Ethics Committee of the Faculty of Medicine of Universitas Muhammadiyah Surakarta (2063/B.1/KEPK-FKUMS/III/2019). Respondents were informed by the interviewers that contribution was voluntary and confidential, and provided written informed consent as proof of approval.

\section{Study period and location}

The study was conducted from December 2019 to February 2020 in Boyolali, Indonesia.

\section{Study design}

This was a concurrent mixed-methods study aiming to explore the use of antibiotics in animal husbandry in a general community in Indonesia. This study is apart from the larger study of knowledge, attitude, and practices toward antibiotics among the general community. The respondents were the general community in Boyolali, a district in Semarang, Indonesia, where antibiotic resistance has been previously reported $[10,11]$. The inclusion criteria for the quantitative study were members of the general community, can communicate well, and willing to participate. The inclusion criteria for the qualitative study were farmers selling animal husbandry products locally and nationally, can communicate well, and willing to participate. The exclusion criterion was an educational or occupational background related to health. The Raosoft sample size calculator was used to calculate the sample size for the quantitative analysis. The margin of error was $5 \%$, the confidence level was $95 \%$, and the response distribution was $50 \%$, but no information regarding the population of residents in the Boyolali Regency was available. Raosoft recommends a population size of 20.000 in this case. The estimate for the minimum sample size was 377 respondents [12]. For the qualitative study, 12 informants were interviewed, and saturation was achieved. Saturation is characterized as a sufficient amount of information of sufficient quality, completeness, and quantity with no evidence of new information in the interviews.

\section{Data collection}

All respondents who fulfilled the inclusion criteria were included using purposive sampling. In the quantitative study, data were collected through a survey using a paper format questionnaire. Respondents who used antibiotics for animal husbandry were then interviewed in-depth using semi-structured interviews with an interview guide. Face-to-face interviews were recorded with a voice recorder. A panel of experts, including community pharmacists, a public health professional, and two physicians, reviewed the questionnaire and interview guide. Before conducting the study, the questionnaire and interview guide were tested in three community participants, but the results were not included in the analysis. Interviews were conducted at the respondent's house, community center, or appointed place between the reviewer and the reviewee. The interview lasted 30-75 min.

\section{Statistical analysis}

Data were analyzed both quantitatively and qualitatively. Descriptive analysis with the mean, standard deviation, and percentages in each category of respondents and the entire sample was applied in the quantitative study. In the qualitative study, data were anonymized on transcription and analyzed with a thematic analysis approach. The transcriptions were read several times to obtain a better view and the keyword or meaning words. The meaning words were then labeled with a code. Different codes were categorized or subcategorized based on the association or similar meaning. The categories with similar meaning were created themes [13]. The transcripts were given to the respondents for clarification, who were asked about any discrepancies with their answers during the interview.

\section{Results}

Of 407 respondents who answered the questionnaire, $42(10.32 \%)$ used antibiotics for animal husbandry; 12 of these respondents were interviewed to obtain a more in-depth understanding of how the antibiotics were used. Of the 42 respondents who used antibiotics for animal husbandry, $>35 \%$ (15 respondents) always bought antibiotics from the pharmacy for animal husbandry without prescription, and 50\% (21 respondents) occasionally used leftover antibiotics for animal husbandry. The types of animals kept included poultry, sheep, cow, duck, fish, and mixed, meaning that some respondents raised more than 1 type of livestock, for example, raising goats and chickens at the same time. The respondent characteristics are described in Table-1. 
Table 1: Characteristics demographic of participants in both quantitative and qualitative studies.

\begin{tabular}{|c|c|c|c|}
\hline Demographic & $\begin{array}{l}\text { Participants fulfilled } \\
\text { questionnaire }(n=407)\end{array}$ & $\begin{array}{l}\text { Participants used antibiotics } \\
\text { for animal husbandry }(n=42)\end{array}$ & $\begin{array}{l}\text { Participants in-depth } \\
\text { interviewed }(n=12)\end{array}$ \\
\hline \multicolumn{4}{|l|}{ Sex } \\
\hline Man & $166(40.8 \%)$ & $21(50.0 \%)$ & $9(75 \%)$ \\
\hline Women & $241(59.2 \%)$ & $21(50.0 \%)$ & $3(25 \%)$ \\
\hline \multicolumn{4}{|l|}{ Age groups (year) } \\
\hline$<20$ & $34(8.4 \%)$ & $7(16.7 \%)$ & - \\
\hline $20-39$ & $245(60.2 \%)$ & $25(59.5 \%)$ & $5(41.7 \%)$ \\
\hline $40-59$ & $115(28.2 \%)$ & $8(19.0 \%)$ & $5(41.7 \%)$ \\
\hline$\geq 60$ & $13(3.2 \%)$ & $2(4.8 \%)$ & $2(16.7 \%)$ \\
\hline Mean (SD) & $35.44(8.06)$ & $29.67(11.86)$ & $42.67(10.16)$ \\
\hline \multicolumn{4}{|l|}{ Education level } \\
\hline $\begin{array}{l}\text { No formal education and } \\
\text { elementary }\end{array}$ & $34(8.4 \%)$ & $1(2.3 \%)$ & $1(8.3 \%)$ \\
\hline Secondary & $275(67.5 \%)$ & $26(61.9 \%)$ & $7(58.3 \%)$ \\
\hline Undergraduate & $96(23.6 \%)$ & $13(31.0 \%)$ & $2(16.7 \%)$ \\
\hline Postgraduate & $2(0.5 \%)$ & $2(4.8 \%)$ & $2(16.7 \%)$ \\
\hline \multicolumn{4}{|c|}{$\begin{array}{l}\text { Respondents bought antibiotics } \\
\text { from pharmacy without prescription }\end{array}$} \\
\hline Never & $318(78.1 \%)$ & - & \\
\hline Seldom & $47(11.5 \%)$ & - & \\
\hline Sometimes & $17(4.2 \%)$ & $17(40.5 \%)$ & \\
\hline Often & $10(2.5 \%)$ & $10(23.8 \%)$ & \\
\hline Always & $15(3.7 \%)$ & $15(35.7 \%)$ & \\
\hline \multicolumn{4}{|c|}{$\begin{array}{l}\text { Respondents gave leftover to animal } \\
\text { husbandry }\end{array}$} \\
\hline Never & $331(81.3 \%)$ & - & \\
\hline Seldom & $42(10.3 \%)$ & $8(19 \%)$ & \\
\hline Sometimes & $21(5.2 \%)$ & $21(50.0 \%)$ & \\
\hline Often & $7(1.7 \%)$ & $7(16.7 \%)$ & \\
\hline Always & $6(1.5 \%)$ & $6(14.3 \%)$ & \\
\hline
\end{tabular}

The result of the qualitative analysis revealed several main themes:

\section{Type of antibiotic used}

The most commonly used antibiotic was Supertetra (Darya-Varia Laboratoria, Indonesia), a trademark of tetracycline and amoxicillin, which was used by $28.7 \%$ of the respondents. Other antibiotics used were benzylpenicillin, gentamicin, ciprofloxacin, oxytetracycline, enrofloxacin, and doxycycline, each of which was used by $7.1 \%$ of respondents. One respondent said: "I give Supertetra ${ }^{\circledR}$ to my cattle if they are injured" (48-year-old woman, N1).

\section{Reasons for antibiotic use}

In this study, large-scale farmers with national-level sales and distribution of poultry explained that they had been using antibiotics as growth promoters in poultry farming for many years. The use of antibiotic growth promoters (AGPs) involves sub-therapeutic doses of antibiotics in animal husbandry, which promote growth from small size to ready to sell. However, since 2017 [14], the use of antibiotics as a feed additive in Indonesia was banned. Hence, the respondents no longer use antibiotics as a feed additive.

One respondent stated: "Before AGPs were banned, antibiotics were included in the list of poultry management programs that were fed to chicks to ready-to-harvest poultry" (35-year-old man, N9).

Aside from AGPs, antibiotics are also administered to animals to prevent disease or as prophylactics. One respondent revealed that when he started catfish farming, he was worried the catfish would be prone to illness. To prevent disease, the respondent fed Supertetra ${ }^{\circledR}$ to the catfish starting from small to the ready-to-harvest sized fish. However, in the following period, the respondent attempted to give antibiotics only to small catfish of 1 month of age because catfish aged $\leq 1$ month are prone to infection.

The respondent stated: "When I first started catfish farming, I fed Supertetra ${ }^{\circledR}$ to my catfish from small to ready-to-harvest size so they are protected from any disease. But after comparing it with using antibiotics as needed, the result is similar. So, I gave antibiotics only to small-sized fish aged $<1$ month" (43-year-old man, N8).

Most respondents gave antibiotics to animals with the intent of treating diseases. Eight respondents fed antibiotics to animals for therapeutic purposes. One respondent gave amoxicillin antibiotics because his poultry lost their appetite. One respondent said: "I administer antibiotics when my cow has a wound on his body" (49-year-old man, N2).

Sources of information regarding the use of antibiotics for animal husbandry practices

One of the respondents obtained information on administering antibiotics from other larger-scale and more experienced farmers. Novice farmers commonly learn about raising livestock from larger-scale and more experienced farmers. Farmers also share information regarding the use of drugs, including antibiotics, in animal husbandry. Four respondents who used antibiotics for therapeutic purposes in animal 
husbandry received information from neighbors with no health education background. One respondent used antibiotics based on personal experience, one fed antibiotics to his animals after receiving information from paramedics, and another said that he generally recommended other farmers to give their animals antibiotics.

"I was told by a neighbor, if the livestock is wounded, it should be given Supertetra ${ }^{\circledR}$ " (48-yearold woman, N1).

Large-scale farmer respondents administered antibiotics to their livestock based on surgical examination of a carcass and standard operating procedures of antibiotic use. The use of antibiotics was based on the veterinarian's suggestion.

"If the poultry are sick, I conduct a carcass surgery and send it to the team; one of them is a veterinarian and he determines the cause of death and whether antibiotics are needed or not" (35-year-old man, N9).

\section{Sources of antibiotics}

Most respondents obtained antibiotics from stalls and animal feed shops. A small percentage of participants bought antibiotics at pharmacies with no prescription. Two participants administered leftover antibiotics to their livestock. A preliminary observation conducted by researchers revealed that of 138 stalls observed, 58 (42\%) sold Supertetra ${ }^{\circledR}$ antibiotics containing tetracycline. Other antibiotics sold at stalls included penicillin, ampicillin, and amoxicillin.

"I buy Supertetra ${ }^{\circledR}$ at a stall" (25-year-old woman, N6).

\section{Antibiotic use in animal husbandry practices}

Almost all respondents used antibiotics in animal husbandry practices incorrectly including the indication, dosage, route, frequency, and duration of antibiotic administration. One respondent used amoxicillin to increase the appetite of his poultry, which is not an indication for amoxicillin. The use of benzylpenicillin followed the correct dose, but the duration was not appropriate. The methods of administering antibiotics to livestock varied, including scattering into ponds, mixing with animal feed or water, sprinkling on wounds, and injecting. For respondents with $>1000$ poultry, if some poultry were diseased, all poultry in the cage were administered antibiotics in their drinking water, although many of the poultry were not sick.

"I open a Supertetra ${ }^{\circledR}$ capsule, I mix it with water, and sprinkle it in the pool. Sometimes, I mix it with fish feed. I feed antibiotics to fish aged $<1$ month for 1 month or to fish that are injured for 3-5 days" (43-year-old man, N8).

"After two rounds of antibiotics without improvement, the poultry were sold. The provision of antibiotics was not only for sick poultry but also for the other thousands of birds in the cage" (35-year-old man, N9).

To accurately determine the diagnosis and select appropriate antibiotics, a veterinary examination is very important, but only two respondents had their animals checked by a veterinarian. Some respondents stated that the reason for not undergoing checks was the cost. Easy access to antibiotics without a prescription was another reason for buying antibiotics directly. Respondents did not know that antibiotics should be obtained from a pharmacy with a physician's prescription. Similar findings have been reported previously [15].

\section{Knowledge of antibiotics and antibiotic resistance}

Most respondents did not know the function and side effects of antibiotics. Information about antibiotics was limited to colleagues or friends with no health education background. The majority of respondents were also unaware of antibiotic resistance and the impact of the inappropriate use of antibiotics on animals and humans. Of all 42 respondents, only three who were undergraduates and postgraduates were able to correctly define the function of antibiotics, had heard of antibiotic resistance, and could define antibiotic resistance.

One respondent said: "I do not understand what resistance is. I have never heard of it" (25-year-old woman, N6).

\section{Discussion}

This study aimed to explore the use of antibiotics in animal husbandry. In this study, the respondents varied in age, education level, and the type of animal husbandry. The most commonly used antibiotics were amoxicillin and tetracycline. The study by Eltayb et al. [16] indicated that the most common antibiotics used by farmers in Sudan were quinolone (32\%) and tetracycline $(25 \%)$. In the current study, two-thirds of farmers used antibiotics for therapeutic purposes. Similar to previous findings, antibiotics were predominantly used for therapeutic and preventive purposes in livestock and only $5 \%$ of farmers used antibiotics as AGPs [16].

The use of antibiotics for animal husbandry practices was primarily not based on recommendations or advice from a veterinarian. Researchers found that respondents mostly referred to personal experience, personal trial and error, and information from friends or other people with no knowledge regarding the use of antibiotics. The majority of respondents used antibiotics inappropriately. In the study by Castro-Sánchez et al. [1], as many as $16 \%(66 / 405)$ of respondents used antibiotics that were not appropriate for healthy livestock.

The inappropriate use of antibiotics in livestock is harmful because there is a high chance of antibiotic residues in meat, eggs, fish, or milk, which elevate potential risks of increasing antibiotic resistance in humans. The respondents reported that if the poultry were not recovering after receiving 10 days of antibiotics treatment, they were sold and consumed by the public. The poultry likely still contained traces of antibiotics, which were then consumed by humans. A study by Unusan [17] in Turkey revealed that dairy 
cows treated with tetracycline and chloramphenicol had high concentrations of those antibiotics in the milk. It is also possible for fish to contain traces of antibiotics because fish cannot metabolize antibiotics effectively and excrete the residue into the environment, resulting in contaminated food supplies and increased antibiotic resistance [18].

The use of antibiotics in animal husbandry practices increases the risk of emerging zoonotic diseases and contributes to the development of antimicrobial resistance in humans and animals $[7,19,20]$. The use of antibiotics in animals can increase the proliferation of resistant bacteria in farm animals. Resistant bacteria can spread to other livestock, the environment, and humans through food products such as meat, eggs, and milk, and also through other routes such as the use of livestock manure for fertilization or direct contact $[5,7,8,18]$. Evidence indicates a relationship between the use of antibiotics in animal husbandry and the occurrence of antibiotic resistance. A study revealed that Salmonella paratyphi-infected broiler barn was resistant to tetracycline, fluoroquinolones, trimethoprim, and cefoxitin [21]. Staphylococcus sp. isolated from a dairy farm and abattoir was resistant to penicillin-G $(95.3 \%)$, nalidixic acid $(88.4 \%)$, cloxacillin $(79.1 \%)$, vancomycin $(65.1 \%)$, and cefoxitin (55.8\%). Staphylococcus sp. is a bacterium that causes mastitis and wound infections in animals and humans [22]. Animal husbandry is the main source of antimicrobial resistance in infections that often occur in humans such as Salmonella, Campylobacter, E. coli, and Enterococci, which are resistant to the third-generation fluoroquinolones and cephalosporin [4].

Of the 42 respondents, only three had heard the word resistance and could define it correctly. These three respondents had undergraduate and postgraduate degrees. The possibility of a relationship between the education level and knowledge of antibiotics was confirmed in the study by Eltayb et al. [16], stating that farmers with $>6$ years' education have better knowledge than those with $\leq 6$ years' education [13].

The inappropriate use of antibiotics by the community in this study was due to the high of cost of veterinary examination, easy access to antibiotics without prescription, and lack of knowledge about antibiotics and antibiotic resistance. This result was in line with a previous report indicating that the level of education, low health literacy, high consultation fees, busy schedules, and unrestricted delivery of antibiotics were key factors associated with the inappropriate use of antibiotics [23,24]. The inappropriate use of antibiotics in animal husbandry will increase bacterial resistance and will also increase costs, reduce food health, negatively impact the environment, increase the use of animal products, and increase the risk of antibiotic side effects in sick and healthy animals $[2,8]$. Thus, the use of antibiotics in animal husbandry needs to be limited [8]. Strategies to reduce the extent of therapeutic antibiotic use are prevention of disease and prudent use of antibiotics. Infection can be prevented with good housing and sanitation by controlling hygiene and environmental quality, optimizing nutrition, and treating infected animals appropriately [25].

\section{Conclusion}

The inappropriate use of antibiotics in animal husbandry was common in the community. This may be due to the lack of knowledge about antibiotics and antibiotic resistance and easy access to obtaining antibiotics. Education regarding the prudent use of antibiotics in animal husbandry practices is needed to reduce the incidence of antibiotic resistance. Education of the regulation of antibiotic use in animals is also important so that the general community can use antibiotics appropriately following the correct indications, applicable laws, and regulations. The role of government is also needed in terms of monitoring the distribution and rational use of antibiotics in the community. Our current findings contribute to our understanding of the use of antibiotics in animal husbandry and provide further insight into designing strategies for health education purposes.

\section{Authors' Contributions}

HK: Designed and conceptualized study, conducted research, collected data, analyzed, and wrote the manuscript. MAAH and SS: Conceptualized study and interpreted data. WII: Provided research material and analyzed data. TT: Interpreted data and provided logistic support. All authors reviewed and approved the final manuscript.

\section{Acknowledgments}

This work was financially supported by Universitas Muhammadiyah Surakarta, Indonesia, with grant number 565/A.3-II/BPSDM/VII/2018. The authors would like to thank all respondents who participated in this study.

\section{Competing Interests}

The authors declare that they have no competing interests.

\section{Publisher's Note}

Veterinary World (Publisher of International Journal of One Health) remains neutral with regard to jurisdictional claims in published institutional affiliation.

\section{References}

1. Castro-Sánchez, E., Moore, L.S.P., Husson, F. and Holmes, A.H. (2016) What are the factors driving antimicrobial resistance? Perspectives from a public event in London, England. BMC Infect. Dis., 16(1): 465.

2. Coyne, L.A., Latham, S.M., Williams, N.J., Dawson, S., Donald, I.J., Pearson, R.B., Smith, R.F. and Pinchbeck, G.L. (2016) Understanding the culture of antimicrobial prescribing in agriculture: A qualitative study of UK pig veterinary surgeons. J. Antimicrob. Chemother., 71(11): 3300-3312.

3. Martin, M.J., Thottathil, S.E. and Newman, T.B. (2015) Antibiotics overuse in animal agriculture: A call to action 
for health care providers. Am. J. Public Health, 105(12): 2409-2410.

4. NethMap. (2018) NethMap 2018: Consumption of Antimicrobial Agents and Antimicrobial Resistance among Medically Important Bacteria in the Netherlands/ MARAN 2018: Monitoring of Antimicrobial Resistance and Antibiotic Usage in Animals in the Netherlands in 2017. Available from: https://www.rivm.openrepository.com/handle/10029/622042. Retrieved on 08-04-2020.

5. Noor, S.M. and Poeloengan, M. (2019) Pemakaian Antibiotik pada Ternak dan Dampaknya pada Kesehatan Manusia. Lokakarya Nasional Keamanan Pangan Produk Peternakan, Bogor.

6. Princeton University. (2019) Antibiotic Resistance in Food Animals Nearly Tripled Since 2000. ScienceDaily; 2019. Available from: https:/www.sciencedaily.com/ releases/2019/10/191009132321.htm. Retrieved on 15-04-2020.

7. Roess, A.A., Winch, P.J., Akhter, A., Afroz, D., Ali, N.A., Shah, R., Begum, N., Seraji, H.R., El Arifeen, S., Darmstadt, G.L. and Baqui, A.H. (2015) Household animal and human medicine use and animal husbandry practices in rural Bangladesh: Risk factors for emerging zoonotic disease and antibiotic resistance. Zoonoses Public Health, 62(7): 569-578.

8. WHO. (2017) WHO Guidelines on Use of Medically Important Antimicrobials in Food-Producing Animals. Available from: https://www.apps.who.int/iris/bitstream/ handle/10665/258970/9789241550130-eng.pdf;jsession$\mathrm{id}=62 \mathrm{D} 838 \mathrm{D} 9 \mathrm{D} 480785 \mathrm{DA} 7 \mathrm{D} 219 \mathrm{E} 2 \mathrm{EAB} 6 \mathrm{C} 0 \mathrm{~B} 5$ ?sequence $=1$. Retrieved on 08-04-2020.

9. Lestari, E.S., Severin, J.A., Filius, P.M.G., Kuntaman, K., Duerink, D.O., Hadi, U., Wahjono, H. and Verbrugh, H.A. (2007) Antimicrobial resistance among commensal isolates of Escherichia coli and Staphylococcus aureus in the Indonesian population inside and outside hospitals. Eur. J. Clin. Microbiol. Infect. Dis., 27(1): 45-51.

10. Parathon, H., Kuntaman, K., Widiastoety, T.H., Muliawan, B.T., Karuniawati, A., Qibtiyah, M., Djanun, Z., Tawilah, J.F., Aditama, T., Thamlikitkul, V. and Vong, S. (2017) Progress towards antimicrobial resistance containment and control in Indonesia. BMJ, 358: j3808.

11. Severin, J.A., Lestari, E.S., Kuntaman, K., Melles, D.C., Pastink, M., Peeters, J.K., Snijders, S.V., Hadi, U., Duerink, D.O., Alex, V.B. and Verbrugh, H.A. (2008) Unusually high prevalence of panton-valentine leukocidin genes among methicillin-sensitive Staphylococcus aureus strains carried in the Indonesian population. J. Clin. Microbiol., 46(6): 1989-1995.

12. Sample Size Calculator by Raosoft, Inc. Available from: http://www.raosoft.com/samplesize.html. Retrieved on 13-09-2019.

13. Maguire, M. and Delahunt, B. (2017) Doing a thematic analysis: A practical, step-by-step guide for learning and teaching scholars. All Ir. J. High. Educ., 9(3): 14.

14. Kementerian Pertanian Republik Indonesia. (2017) Peraturan Menteri Pertanian Republik Indonesia Nomor 14/ Permentan/Pk.350/5/2017 Tentang Klasifikasi Obat Hewan. Kementerian Pertanian Republik Indonesia, Jakarta.

15. Karuniawati, H., Hassali, M.A.A., Suryawati, S., Ismail, W.I., Taufik, T. and Wiladatika, A. (2020) Public practices towards antibiotics: A qualitative study. Clin. Epidemiol. Glob. Health, 8(4): 1277-1281.

16. Eltayb, A., Barakat, S., Marrone, G., Shaddad, S. and Lundborg, C.S. (2012) Antibiotic use and resistance in animal farming: A quantitative and qualitative study on knowledge and practices among farmers in Khartoum, Sudan. Zoonoses Public Health, 59(5): 330-338.

17. Unusan, N. (2009) Occurrence of chloramphenicol, streptomycin and tetracycline residues in ultra-heat-treatment milk marketed in Turkey. Int. J. Food Sci. Nutr., 60(5): 359-364.

18. Meade, E., Slattery, M.A. and Garvey, M. (2017) Antimicrobial resistance: An agent in zoonotic disease and increased morbidity. J. Clin. Exp. Toxicol., 1(1): 30-37. Available from: https://www.alliedacademies.org/ abstract/antimicrobial-resistance-an-agent-in-zoonotic-disease-and-increased-morbidity-9144.html. Retrieved on 24-11-2020.

19. Speksnijder, D.C., Mevius, D.J., Bruschke, C.J.M. and Wagenaar, J.A. (2015) Reduction of veterinary antimicrobial use in the Netherlands. The Dutch success model. Zoonoses Public Health, 62(Suppl 1): 79-87.

20. Sidikou, D.I., Caron, Y., Delguste, C., Ibrahim, A.I., Ibrahim, M.L., Adakal, H., Hornick, J.L. and AntoineMoussiaux, N. (2020) Teaching one health: Animal husbandry in a post-graduate interdisciplinary curriculum. Int. J. One Health, 6(1): 69-75.

21. Kloska, F., Beyerbach, M. and Klein, G. (2017) Infection dynamics and antimicrobial resistance profile of Salmonella paratyphi B d-tartrate positive (Java) in a persistently infected broiler barn. Int. J. Environ. Res. Public Health, 14(1): 101 .

22. Beyene, T., Hayishe, H., Gizaw, F., Beyi, A.F., Abunna, F., Mammo, B., Ayana, D., Waktole, H. and Abdi, R.D. (2017) Prevalence and antimicrobial resistance profile of Staphylococcus in dairy farms, abattoir and humans in Addis Ababa, Ethiopia. BMC Res. Notes, 10(1): 171.

23. Atif, M., Asghar, S., Mushtaq, I., Malik, I., Amin, A., Babar, Z.U.D. and Scahill, S. (2019) What drives inappropriate use of antibiotics? A mixed-methods study from Bahawalpur, Pakistan. Infect. Drug Resist., 12: 687-699.

24. Gebeyehu, E., Bantie, L. and Azage, M. (2015) Inappropriate use of antibiotics and its associated factors among urban and rural communities of Bahir Dar city administration, Northwest Ethiopia. PLos One, 10(9): e0138179.

25. National Research Council (US) Committee on Drug Use in Food. (1999) The Use of Drugs in Food Animals: Benefits and Risks. National Academies Press, Washington, DC. 